\title{
OPTIMIZATION OF ANAEROBIC TREATMENT OF CASSAVA PROCESSING
} WASTEWATER

Doi:http://dx.doi.org/10.1590/1809-4430-Eng.Agric.v37n3p574-590/2017

\section{LEANDRO FLECK ${ }^{*}$, MARIA H. F. TAVARES ${ }^{2}$, EDUARDO EYNG ${ }^{3}$, MINÉIA A. DE M. DE ANDRADE ${ }^{4}$, LAERCIO M. FRARE ${ }^{3}$}

\author{
1* Corresponding author. Universidade Estadual do Oeste do Paraná - UNIOESTE/ Cascavel - PR, Brasil. \\ E-mail: fleckmissal@gmail.com
}

\begin{abstract}
The main contribution of this research is to optimize the operating conditions of an anaerobic reactor applied to the treatment of wastewater from cassava starch production. A 20-L anaerobic reactor was used, operating in a batch system, with temperature control. Temperature and inoculum total volatile solids $\left(\mathrm{TVS}_{\mathrm{i}}\right)$ were controlled for evaluation of effects on the removals of chemical oxygen demand (COD) and reactor total volatile solids $\left(\mathrm{TVS}_{\mathrm{r}}\right)$ by means of a Central Composite Rotational Design (CCRD). Twelve trials were analyzed simultaneously by the desirable function approach. The higher COD removal (96.82\%) was obtained at $42{ }^{\circ} \mathrm{C}$ and $12.0 \% \mathrm{TVS}_{\mathrm{i}}$. The largest $\mathrm{TVS}_{\mathrm{r}}$ removal $(69.31 \%)$ was registered at $45{ }^{\circ} \mathrm{C}$ and $10.0 \% \mathrm{TVS}_{\mathrm{i}}$. Equations representative of the process were obtained from the responses of variables, being statistically significant at a $90 \%$ confidence level. Based on the desirability function approach, we can conclude that an optimal operational condition for the anaerobic reactor is at $39.7^{\circ} \mathrm{C}$ and $10.8 \% \mathrm{TVS}_{\mathrm{i}}$. The estimated COD and $\mathrm{TVS}_{\mathrm{r}}$ removal efficiencies under these operating conditions were $90.45 \%$ and $63.12 \%$, respectively.
\end{abstract}

KEYWORDS: anaerobic reactor, biogas, desirability function, mathematical modeling.

\section{INTRODUCTION}

In recent years, a high generation of organic waste has been a direct result of an accelerated industrial growth (JIA et al., 2013), exceeding natural recycling capacity through the terrestrial biosphere. This issue suggests the need to develop and improve waste treatment techniques. In the context of food production, cassava starch factories (Manihot esculenta Crantz), for example, deserve special attention in view of the high pollution potential of the wastewater from the processing of the roots for starch (ZHANG et al., 2011). However, according to WANG et al. (2012), only in recent years, studies related to the treatment of wastewater from cassava processing have been carried out as a way to reduce pollution potential.

One of the possibilities is the use of anaerobic biodigestion (FERRAZ et al., 2009; KUCZMAN et al., 2014; INTANOO et al., 2014) which, according to MIRANDA et al. (2012), is an effective technique and has the major advantage of being a biogas plant, being a high-energy power generation system. The anaerobic biodigestion consists of an ecosystem in which different groups of microorganisms, under stringent conditions of oxygen, work interactively converting complex organic matter into methane $\left(\mathrm{CH}_{4}\right)$, carbon dioxide $\left(\mathrm{CO}_{2}\right)$, water, hydrogen sulfide $\left(\mathrm{H}_{2} \mathrm{~S}\right)$, ammonia $\left(\mathrm{NH}_{3}{ }^{+}\right)$, and new bacterial cells (KPATA-KONAN et al., 2013; SCHIRMER et al., 2014).

For a maximum and steady biogas production via anaerobic biodigestion, factors directly influencing the process must be monitored, and the process thus optimized (AHLBERGALIASSON et al., 2017). Some of the factors to be monitored are temperature, $\mathrm{pH}$, substrate composition, carbon/ nitrogen ratio, time retention, alkalinity, and content of volatile solids in the inoculum (KUMAR \& LIN, 2013; KWIETNIEWSKA \& TYS, 2014; DOBRE et al., 2014).

\footnotetext{
${ }^{2}$ Universidade Estadual do Oeste do Paraná - UNIOESTE/ Cascavel - PR, Brasil.

${ }^{3}$ Universidade Tecnológica Federal do Paraná - UTFPR/ Medianeira - PR, Brasil.

${ }^{4}$ Universidade Estadual Paulista - UNESP/ Sorocaba - SP, Brasil.

Received in: 10-10-2016

Accepted in: 1-30-2017
} 
Three temperature regimes can be used in anaerobic digesters: psychrophilic, mesophilic, and thermophilic. Psychrophilic microorganisms operate at temperatures close to $20{ }^{\circ} \mathrm{C}$, mesophilic ones at around $35^{\circ} \mathrm{C}$, and thermophilic near $55^{\circ} \mathrm{C}$ (JAIN et al., 2015). Increasing temperature has a positive effect on the metabolic rate of the microorganisms and the process runs faster (KARAGIANNIDIS \& PERKOULIDIS, 2009). Another factor influencing the fermentation process is $\mathrm{pH}$ (MÉNDEZ-ACOSTA et al., 2013); with 6.8-7.2 being, the most favorable range for anaerobic digestion (WARD et al., 2008).

The anaerobic biodigestion may be used for treating wastewater from cassava starch production, in order to control several environmental factors of interest during the process (KPATA-KONAN et al., 2013; KULLAVANIJAYA \& THONGDUANG, 2012; KUNZLER et al., 2013; KUCZMAN et al., 2014). According to ZENG et al. (2010), in the case of a batch process and based on volatile solids, a proper inoculum/substrate ratio (ISR) is a key factor for anaerobic digestion, increasing the efficiency of treatment. Unfortunately, there are few studies developed to assess the influence of such variable on the treatment of wastewater from cassava starch production.

In this context, the main contribution of this paper is to obtain the best system operation conditions by changing temperature and rate of total volatile solids in the inoculum $\left(\mathrm{TVS}_{\mathrm{i}}\right)$, verifying which provide great reductions of carbonaceous organic material and reactor total volatile solids $\left(\mathrm{TVS}_{\mathrm{r}}\right)$. In short, this study focused on optimizing the operating conditions of an anaerobic reactor applied to the treatment of wastewater from cassava starch. Finally, we could use the results to model the process efficiency according to the evaluated variables.

\section{MATERIAL AND METHODS}

\section{Experimental Module}

Figure 1 shows an illustration of the experimental module consisting of an anaerobic reactor (1a) operating in a batch system. The jacketed anaerobic reactor was built in PVC (polyvinyl chloride) with a volume of $20 \mathrm{~L}$. Temperature control was carried out by recirculating from a cold storage (1b) within a heating range from 25 to $90{ }^{\circ} \mathrm{C}$, using a recirculating water pump (1c).

The reactor was connected to a gasometer located externally to the system, where a silicone hose was adapted to lead the biogas into the gasometer. The pipes composing the gasometer 1(d) and 1(e) were filled with acidified saline solution of sulfuric acid $\left(\mathrm{H}_{2} \mathrm{SO}_{4}\right)$ and sodium sulfate decahydrate $\left(\mathrm{Na}_{2} \mathrm{SO}_{4} \cdot 10 \mathrm{H}_{2} \mathrm{O}\right)$; as such, dissolution of the gasses from the process could be avoided, enhancing the biogas quantification accuracy.

The biogas produced in the reactor was led into the gasometer, promoting the displacement of the acidified saline solution inside smaller pipes 1(d) towards the larger pipes 1(e) of gasometer based on the principle of communicating vessels and, thereby, enabling biogas daily quantification. Figure 1(g) displays the displacement of acidified saline solution as a function of biogas production. By comparison, Figure 1(f) shows how the system works when there is no biogas production. 
Tag names

1(a) jacketed anaerobic reactor

1(b) water heating system

1(c) water recirculation pump

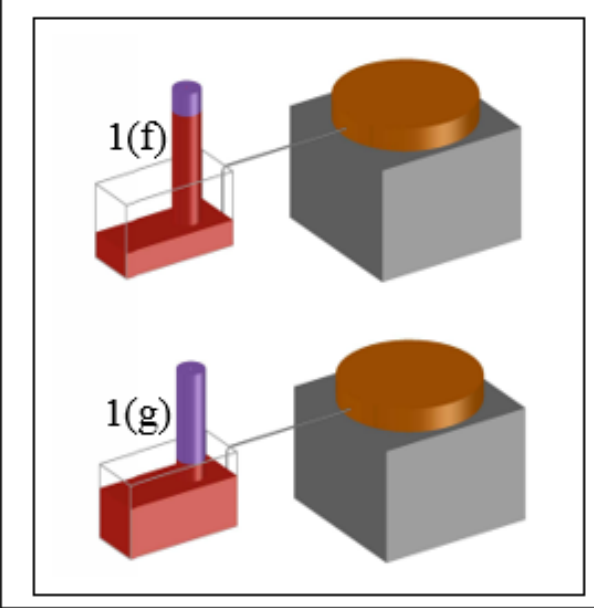

1(d) gasometer smaller pipe

1(e) gasometer larger pipe

1(f), 1(g) displacement of the acidified saline solution

FIGURE 1. Experimental Module.

\section{Substrate}

Anaerobic digestion used wastewater from cassava processing as a substrate; this residue was kindly provided by a starch manufacturer from Western Paraná state - Brazil (Latitude: -24.427466, Longitude: -53.979081; Elevation: $346 \mathrm{~m}$ ). The effluent was previously characterized by determining the biochemical oxygen demand (BOD), chemical oxygen demand (COD), total Kjeldahl nitrogen (TKN), phosphorus (P), total alkalinity, total fixed and volatile solids, $\mathrm{pH}$, and starch concentration following the methodologies presented in Table 1.

TABLE 1. Methods for wastewater characterization.

\begin{tabular}{lc}
\hline Variables & Methodology \\
\hline BOD & Method 5210B (APHA, 2012) \\
COD & Method 5220B (APHA, 2012) \\
TKN & Method 4500-Norg-C (APHA, 2012) \\
P & Method 4500E (APHA, 2012) \\
Total Alkalinity & Method 2320B (APHA, 2012) \\
Total Solids, Fixed and Volatile & Method 2540G (APHA, 2012) \\
pH & Method 4500 B (APHA, 2012) \\
Starch & Acid digestion in microwaves (CEREDA et al., 2004) \\
\hline
\end{tabular}

The wastewater was pre-treated to determine the amount of starch and impurities at the end of the process. For this purpose, starch was separated by decantation. Before characterization, wastewater passed through sieves to eliminate coarse solid waste, such as cassava husk. However, the contents of starch and coarse solids were low after decantation and sieving. Immediately afterward, wastewater was ready for experimental trials without requiring any removal of impurities.

\section{Inoculum}

The sludge of an anaerobic biodigester was used as inoculum, which is applied to the treatment of wastewater from cassava starch production, being the same effluent as that collected for the experimental trials. Each temperature testing was preceded by biomass acclimatization to the 
new operating conditions. Prior to performing experimental tests, total volatile solids $\left(\mathrm{TSV}_{\mathrm{i}}\right.$ ) were determined by the gravimetric method 2540B (APHA, 2012) since it is an indicator of biologically active biomass responsible for the biological treatment of wastewater.

\section{Optimization of the anaerobic biodigestion process}

After controlling the temperature and the amount of inoculum total volatile solids $\left(\mathrm{TVS}_{\mathrm{i}}\right)$, we evaluated further effects on the removal of carbonaceous organic matter in terms of COD and reactor total volatile solids $\left(\mathrm{TVS}_{\mathrm{r}}\right.$ ), which consists of total volatile solids in the reactor (sum of inoculum and substrate total volatile solids). This evaluation was made using a Central Composite Rotational Design (CCRD), which is a factorial scheme of treatments $\left(2^{2}\right)$, with 4 factorials, 4 axial points, and 4 replications on the central point, totaling 12 assays. Table 2 shows the matrix of treatments with encoded and real values of the factors. For each assay, there was the mixture of inoculum and wastewater to obtain the conditions of $\mathrm{TSV}_{\mathrm{i}}$ as established by the CCRD matrix.

TABLE 2. Treatment design matrix.

\begin{tabular}{lccccc}
\hline Trial & \multicolumn{2}{c}{ Temperature } & & \multicolumn{2}{c}{ TVS $_{\mathrm{i}}$} \\
\cline { 2 - 3 } \cline { 5 - 6 } & Encoded Values & $\begin{array}{c}\text { Real } \\
\text { Values }\left({ }^{\circ} \mathrm{C}\right)\end{array}$ & & $\begin{array}{c}\text { Encoded } \\
\text { Values }\end{array}$ & $\begin{array}{c}\text { Real } \\
\text { Values }(\%)\end{array}$ \\
\hline 1 & -1 & 28 & & -1 & 8.0 \\
2 & -1 & 28 & & 1 & 12.0 \\
3 & 1 & 42 & & -1 & 8.0 \\
4 & 1 & 42 & & 1 & 12.0 \\
5 & -1.41 & 25 & & 0 & 10.0 \\
6 & 1.41 & 45 & & 0 & 10.0 \\
7 & 0 & 35 & & -1.41 & 7.2 \\
8 & 0 & 35 & & 1.41 & 12.8 \\
9 & 0 & 35 & & 0 & 10.0 \\
10 & 0 & 35 & & 0 & 10.0 \\
11 & 0 & 35 & & 0 & 10.0 \\
12 & 0 & 35 & & 0 & \\
\hline
\end{tabular}

Wastewater Hydraulic Retention Time (HRT) under anaerobic oxidation was set at 15 days for all treatments, being defined by preliminary tests. A continuous mechanical stirring was carried out for sludge disturbance in the reactor.

Wastewater samples were collected at the beginning and at the end of each trial for COD and $\mathrm{TVS}_{\mathrm{r}}$ analyses, following the methodologies shown in Table 1. From the data obtained, the efficiency of carbonaceous oxidation could be ascertained in terms of COD and $\mathrm{TVS}_{\mathrm{r}}$ removal, according to the eqs (1) and (2), respectively:

$$
\begin{aligned}
& \text { Removal COD }(\%)=\left(\frac{\mathrm{COD}_{\text {initial }}-\mathrm{COD}_{\text {final }}}{\mathrm{COD}_{\text {initial }}}\right) \times 100 \\
& \text { Removal TVS } \mathrm{r}(\%)=\left(\frac{\mathrm{TVS}_{\mathrm{r}_{\text {initial }}}-\mathrm{TVS}_{\mathrm{r} \text { final }}}{\mathrm{TVS}_{\text {rinitial }}}\right) \times 100
\end{aligned}
$$

During the experimental phase, when the $\mathrm{pH}$ drops below neutrality, sodium hydroxide $(\mathrm{NaOH})(1 \mathrm{M})$ was added to adjust it $7.0 \pm 0.5$, which is required to ensure buffering conditions and reactor stability.

For each response-variable, a quadratic mathematical model representative of the process was developed from a statistical adjustment of the results, corresponding to all treatments, using 
Statistica software version 7.0 (StatSoft, Tulsa, OK, USA). The mathematical models to encode the removal rates of COD and $\mathrm{TVS}_{\mathrm{r}}$ are shown in the eqs (3) and (4), respectively:

$$
\begin{aligned}
& \text { Removal COD }(\%)=\alpha+\alpha_{1} x_{1}+\alpha_{11} x_{1}^{2}+\alpha_{2} x_{2}+\alpha_{22} x_{2}^{2}+\alpha_{12} x_{1} x_{2} \\
& \text { RemovalTVS }(\%)=\beta_{0}+\beta_{1} x_{1}+\beta_{11} x_{1}^{2}+\beta_{2} x_{2}+\beta_{22} x_{2}^{2}+\beta_{12} x_{1} x_{2}
\end{aligned}
$$

where,

$\alpha$ and $\beta=$ parameters of the regression model;

$\mathrm{x}_{1}=$ encoded value of temperature,

$\mathrm{x}_{2}=$ encoded value of the rate of total volatile solids in inoculum.

The use of quadratic models allows the optimization of the process by estimating secondorder surface models, which relate the analyzed factors to the response variables (JUMBRI et al., 2015). Several studies have aimed at optimizing the treatment of organic residues. Such studies have been controlling several environmental factors which exert an influence on anaerobic biodigestion efficiency with the purpose of finding an optimal configuration, just based on quadratic models (DAHUNSI et al., 2016; CHAN et al., 2015).

In order to assess response-variables simultaneously and to find optimum operating values for controlled independent variables in the system, we applied the desirability function approach, as proposed by DERRINGER \& SUICH (1980), using Statistica software (v. 7.0).

Statistical significance of the mathematical models was tested by analysis of variance (ANOVA) at a 90\% confidence level and, subsequently, validated based on COD and $\mathrm{TVS}_{\mathrm{r}}$ removal efficiency data from a validation test. The operational conditions (temperature and $\mathrm{TVS}_{\mathrm{i}}$ ) used in validation test were obtained by applying the desirability function.

\section{Quantification of the generated biogas}

The following information was recorded daily about biogas: produced volume (L), reactor temperature (TFA-Dostmann thermometer), acidified saline solution temperature (TFA-Dostmann thermometer), levels (height) of acidified saline solution in large and small piping systems (Figure 1) for estimation of the difference between internal and atmospheric pressures (Barometer Torricelli). The volume of biogas produced was corrected to the standard temperature and pressure (STP) conditions by the [eq. (5)]:

$$
\mathrm{V}_{\mathrm{p}}=\mathrm{V}_{\mathrm{L}} \frac{\mathrm{T}_{\mathrm{p}}}{\mathrm{T}_{\mathrm{A}}}\left(\frac{\mathrm{P}_{\text {int }}-\mathrm{P}_{\mathrm{w}}}{\mathrm{P}_{\mathrm{p}}}\right)
$$

where,

$\mathrm{V}_{\mathrm{p}}=$ standardized biogas volume $\left(\mathrm{L}_{\mathrm{N}}\right)$;

$\mathrm{V}_{\mathrm{L}}=$ biogas volume registered by the gasometer $(\mathrm{L})$;

$\mathrm{T}_{\mathrm{p}}=$ standard temperature $(273 \mathrm{~K})$;

$\mathrm{T}_{\mathrm{A}}=$ room temperature $(\mathrm{K})$;

$\mathrm{P}_{\text {int }}=$ internal pressure (mbar);

$\mathrm{P}_{\mathrm{w}}=$ steam water pressure (mbar),

$\mathrm{P}_{\mathrm{p}}=$ standardized pressure $(1,013.25 \mathrm{mbar})$.

The internal pressure of the gasometer was calculated from the [eq. (6)]. 


$$
P_{\text {int }}=\left(P_{\text {atm }}+\rho g h\right)
$$

where,

$$
\begin{aligned}
& P_{\text {int }}=\text { internal pressure }(\mathrm{Pa}) ; \\
& P_{\text {atm }}=\text { atmospheric pressure }(\mathrm{Pa}) ; \\
& \rho=\text { density of the acidified saline solution }\left(\mathrm{kg} \mathrm{m}^{-3}\right) ; \\
& \mathrm{g}=\text { gravity }\left(\mathrm{m} \mathrm{s}^{-2}\right), \\
& \mathrm{h}=\text { difference (height) between acidified saline solution levels in the larger and smaller piping }(\mathrm{m}) .
\end{aligned}
$$

It is believed that water steam may overestimate the biogas volume by 2 to $8 \%$ under normal conditions of temperature and atmospheric pressure. Thus, the steam pressure of water $\left(\mathrm{P}_{\mathrm{w}}\right)$ was considered obtain most exact measurements of biogas through [eq. (7)] (STRÖMBERG et al., 2014).

$$
\mathrm{P}_{\mathrm{w}}=\left(10^{8,1962}-\frac{1730,63}{\mathrm{~T}_{\mathrm{A}}-39,724}\right) * 100
$$

where,

$$
\begin{aligned}
& \mathrm{P}_{\mathrm{W}}=\text { steam pressure }(\mathrm{Pa}), \\
& \mathrm{T}_{\mathrm{A}}=\text { room temperature }(\mathrm{K}) .
\end{aligned}
$$

The biogas composition was determined by gas chromatography (GC) with weekly sampling. In each analysis, an aliquot of $0.5 \mathrm{~mL}$ biogas was collected with a $2.5-\mathrm{mL}$ glass syringe (HamiltonGastight) for determining the percentage of methane, carbon dioxide, and hydrogen sulfide. The analysis was performed through GC with thermal conductivity detector (TCD), Plot Q column packed with $30 \mathrm{~m}$ length and an internal diameter of $0.32 \mathrm{~mm}$, using helium as carrier gas. Biogas composition was determined from calibration curves constructed using reference standards (synthetic biogas) by different dilutions. The calibration curves were built for the concentrations of $\mathrm{CH}_{4}, \mathrm{CO}_{2}$, and $\mathrm{H}_{2} \mathrm{~S}$, by means of linear regression. For each weekly analysis, done in triplicate, the areas of chromatogram peaks were placed in the calibration curves to determine the percentage of each constituent of the biogas generated in the treatment.

The biogas production was monitored until a daily-generated volume no higher than $1 \%$ total cumulative volume, as proposed by MONDARDO et al. (2016). The process stability was monitored by the analysis of parameters as $\mathrm{pH}, \mathrm{COD}$, and $\mathrm{TVS}_{\mathrm{r}}$, according to the methods set forth in Table 1. Furthermore, following recommendations of RIPLEY et al. (1986), the intermediate alkalinity and partial alkalinity ratio (IA/PA) was monitored to ensure that this proportion remains close to 0.3 . Whenever necessary, sodium hydroxide $(\mathrm{NaOH})(1 \mathrm{M})$ was added to the anaerobic reactor to provide alkalinity to the mixture.

\section{RESULTS AND DISCUSSION}

\section{Wastewater characterization}

The main physical and chemical characteristics of wastewater from cassava starch production of this study are shown in Table 3. As the COD/BOD ratio is 4.2, the wastewater can be considered biodegradable only if the factors influencing the process are suitable for microbial metabolism. If the ratio is $5.0>\mathrm{COD} / \mathrm{BOD}>2.5$, a proper biological process should be chosen in order to reach a desirable reduction of organic matter (LOURES et al., 2014).

The $\mathrm{pH}$ of the wastewater is 4.02 , which is near the 4.37 found by KUCZMAN et al. (2011); conversely, the concentration of total volatile solids was $5151 \mathrm{mg} \mathrm{L}^{-1}$, being lower than the value 
found by the same authors $\left(7510 \mathrm{mg} \mathrm{L}^{-1}\right)$. The starch content of the wastewater is $3.20 \%$, which is below the $6.3 \%$ found by SUMAN et al. (2011). A low starch content is important since its molecular structure, formed by sugars of easy decomposition, generates acids that become improper substrates for methanogenic bacteria development.

TABLE 3. Characterization of wastewater from cassava starch production.

\begin{tabular}{lcc}
\hline Variable & Value & Unity \\
\hline DQO & 6014 & $\mathrm{mg} \mathrm{L}^{-1}$ \\
DBO & 1400 & $\mathrm{mg} \mathrm{L}^{-1}$ \\
Starch concentration & 3.20 & $\%$ \\
Total nitrogen & 247 & $\mathrm{mg} \mathrm{L}^{-1}$ \\
Phosphor & 83 & $\mathrm{mg} \mathrm{L}^{-1}$ \\
Total alkalinity & 2021 & $\mathrm{mg} \mathrm{L}^{-1}$ \\
pH & 4.02 & - \\
Total solids & 6581 & $\mathrm{mg} \mathrm{L}^{-1}$ \\
Total fixed solids & 1431 & $\mathrm{mg} \mathrm{L}^{-1}$ \\
Total Volatile Solids & 5151 & $\mathrm{mg} \mathrm{L}^{-1}$ \\
\hline
\end{tabular}

\section{COD and TVS removals}

The $\mathrm{TVS}_{\mathrm{r}}$ and COD removal efficiencies are shown in Table 4. It can be seen an increased COD removal at $42{ }^{\circ} \mathrm{C}$ and $12.0 \% \mathrm{TVS}_{\mathrm{i}}$ and at $35{ }^{\circ} \mathrm{C}$ and $10.0 \%$ of $\mathrm{TVS}_{\mathrm{i}}$, which accounted for $96.82 \%$ and $92.05 \%$ (mean values), respectively. A similar result was obtained by FERRAZ et al. (2009) who evaluated the performance of an anaerobic baffled reactor (ABR) for treatment of wastewater from cassava processing at $35{ }^{\circ} \mathrm{C}$; they reported a COD removal ranging from 83-92\%. The lower COD efficiency (12.44\%) occurred under the conditions of $42{ }^{\circ} \mathrm{C}$ and $8.0 \%$ of $\mathrm{TVS}_{\mathrm{i}}$.

The highest removal of reactor total volatile solids $\left(\mathrm{TVS}_{\mathrm{r}}\right)$ was $69.31 \%$ and occurred at $45{ }^{\circ} \mathrm{C}$ and $10.0 \% \mathrm{TVS}_{\mathrm{i}}$. Yet the least removal was $18.51 \%$ at $25^{\circ} \mathrm{C}$ and $10.0 \% \mathrm{TVS}_{\mathrm{i}}$. Both the highest and lowest $\mathrm{TVS}_{\mathrm{r}}$ values took place respectively at the highest and lowest system temperatures; therefore, it is strong indication that temperature may significantly influence the $\mathrm{TVS}_{\mathrm{r}}$ process. KUCZMAN et al. (2014) evaluated cassava processing wastewater treatment by a pilot horizontal tubular anaerobic reactor filled with bamboo pieces, and registered a $75.56 \%$ removal of volatile solids for an HRT of 13 days, being higher than those found in the present study. These results are related to the use of a support medium in the anaerobic reactor, which increases the contact area of microorganisms with wastewater, providing greater microbial biomass activity and growth (ADUGYAMFI et al., 2012).

According to RIPLEY et al. (1986), IA/PA ratio greater than 0.3 may indicate disturbances in anaerobic biodigestion since partial alkalinity is related to bicarbonate ions maintaining $\mathrm{pH}$ without major alterations, thus favoring biological activity in the environment. At the end of the process, a few of the runs of CCRD show IA/PA ratio above the limit (see Table 4). Nonetheless, according to PEREIRA et al. (2009), each effluent has peculiarities that might keep process stability with values different of 0.3 . Hence, the good efficiency of organic matter removal, even under IA/ PA ratios above 0.3 , there was stability in the anaerobic reactor tested in this study. Furthermore, $\mathrm{pH}$ remained within the optimal range for anaerobic biodigestion (6.8-7.2) (WARD et al., 2008) for all experiments. It demonstrates the system capacity of handling the oscillations by acid generation (PEREIRA et al., 2013). 
TABLE 4. Removal of chemical oxygen demand and total volatile solids in the reactor.

\begin{tabular}{lllccc}
\hline Trial & Temperature $\left({ }^{\circ} \mathrm{C}\right)$ & $\begin{array}{c}\mathrm{TVS}_{\mathrm{i}} \\
(\%)\end{array}$ & $\begin{array}{c}\text { COD Removal } \\
(\%)\end{array}$ & TVS $_{\mathrm{r}}$ Removal $(\%)$ & IA/PA final ratio \\
\hline 1 & 28 & 8.0 & 41.53 & 21.90 & 0.35 \\
2 & 28 & 12.0 & 32.01 & 55.10 & 0.32 \\
3 & 42 & 8.0 & 12.44 & 40.52 & 0.33 \\
4 & 42 & 12.0 & 96.82 & 68.90 & 0.26 \\
5 & 25 & 10.0 & 31.70 & 18.51 & 0.30 \\
6 & 45 & 10.0 & 58.49 & 69.31 & 0.40 \\
7 & 35 & 7.2 & 14.14 & 27.97 & 0.32 \\
8 & 35 & 12.8 & 26.71 & 33.56 & 0.29 \\
9 & 35 & 10.0 & 95.09 & 63.10 & 0.30 \\
10 & 35 & 10.0 & 90.10 & 60.30 & 0.28 \\
11 & 35 & 10.0 & 94.51 & 57.60 & 0.38 \\
12 & 35 & 10.0 & 88.50 & 59.10 & 0.33 \\
\hline
\end{tabular}

\section{Biogas production and characterization}

Table 5 represents the biogas production for the different experimental conditions of the CCRD. For $35{ }^{\circ} \mathrm{C}$ and $10.0 \% \mathrm{TVS}_{\mathrm{i}}$, production was $0.317 \mathrm{~L}_{\mathrm{N}}$ biogas per g COD removed, being near that of $0.368 \mathrm{~L}_{\mathrm{N}}$ biogas per g COD removed (13 days HRT), found by KUCZMAN et al. (2014).

The explanation for such discrepant biogas production, under the aforementioned conditions, is due to an intrinsic variability in the biological process during wastewater treatment. In addition, according to KWIETNIEWSKA \& TYS (2014), there are other factors disregarded in the present study, which can directly influence the biogas production in anaerobic processes, e.g. substrate toxic substances. The focus here was on evaluating the treatment of wastewater from a cassava starch production by means of quantifying COD and $\mathrm{TVS}_{\mathrm{r}}$ removals. Ergo, biogas production was one of the additional advantages from biodigestion. As can be observed in Table 4, the results were satisfactory and with good repeatability, allowing the mathematical modeling of the responsevariables.

All treatments produced biogas with methane concentrations above 50\%, showing its quality in terms of calorific value. Conversely, hydrogen sulfide $\left(\mathrm{H}_{2} \mathrm{~S}\right)$ concentration was low in all tests, which, according to IOVANE et al. (2014), is extremely important because it corrodes pipes and engines, being also toxic to humans.

Besides methane, carbon dioxide, and hydrogen sulfide, other chemical compounds were found in biogas samples, which were not quantified separately by gas chromatography, e.g. water vapor, air, hydrogen, ethane, propane, butane, and carbon monoxide. NOOR et al. (2014) describe the presence of these constituents in biogas at concentrations lower than methane and carbon dioxide; however, according to AWE et al. (2017), the raw biogas has to be purified to increase its quality and applicability standards. In short, these compounds made up at most $22.45 \%$ of the biogas composition. Air insertion into the biogas may have occurred at the time of collection, even though we used a glass syringe with high insulation capacity (Hamilton-Gastight). 
TABLE 5. Biogas production and characterization.

\begin{tabular}{|c|c|c|c|c|c|c|c|}
\hline \multirow[t]{3}{*}{ Trial } & \multirow{2}{*}{\multicolumn{2}{|c|}{$\begin{array}{l}\text { Experimental } \\
\text { conditions }\end{array}$}} & \multirow{3}{*}{$\begin{array}{l}\text { Biogas Production } \\
\left(\mathrm{L}_{\mathrm{N}} \text { biogas } \mathrm{g}^{-1} \mathrm{COD}\right. \\
\text { removed })\end{array}$} & \multicolumn{4}{|c|}{ Characterization Biogas (\%) } \\
\hline & & & & \multirow{2}{*}{$\mathrm{CH}_{4}$} & \multirow{2}{*}{$\mathrm{CO}_{2}$} & \multirow{2}{*}{$\mathrm{H}_{2} \mathrm{~S}$} & \multirow{2}{*}{ Others } \\
\hline & $\mathrm{T}\left({ }^{\circ} \mathrm{C}\right)$ & $\mathrm{TVS}_{\mathrm{i}}(\%)$ & & & & & \\
\hline 1 & 28 & 8.0 & 0.154 & 63.25 & 32.81 & - & 3.94 \\
\hline 2 & 28 & 12.0 & 0.066 & 61.00 & 20.00 & - & 19.00 \\
\hline 3 & 42 & 8.0 & 0.291 & 55.23 & 22.30 & 0.02 & 22.45 \\
\hline 4 & 42 & 12.0 & 0.002 & 57.20 & 33.51 & 0.01 & 9.28 \\
\hline 5 & 25 & 10.0 & 0.070 & 58.25 & 20.12 & - & 21.63 \\
\hline 6 & 45 & 10.0 & 0.158 & 57.23 & 21.26 & - & 21.51 \\
\hline 7 & 35 & 7.2 & 0.194 & 71.00 & 29.00 & - & - \\
\hline 8 & 35 & 12.8 & 0.158 & 65.00 & 35.00 & - & - \\
\hline 9 & 35 & 10.0 & 0.317 & 63.21 & 20.32 & - & 16.47 \\
\hline 10 & 35 & 10.0 & 0.000 & - & - & - & - \\
\hline 11 & 35 & 10.0 & 0.163 & 65.11 & 14.09 & 0.01 & 20.79 \\
\hline 12 & 35 & 10.0 & 0.071 & 62.52 & 30.67 & 0.24 & 3.57 \\
\hline
\end{tabular}

Influence of the studied factors on removal of COD and TVS

Table 6 shows that all factors influenced significantly the COD removal since p-value is below the standard, at a 10\% significance. RODRIGUES \& IEMMA (2009) stated that given the great variability in the treatment of effluents using microorganisms, the variables with $\mathrm{p}$ values lower than $10 \%(\mathrm{p}<0.1)$ should be considered.

Our results are consistent because, according to KWIETNIEWSKA \& TYS (2014), they operate under mesophilic conditions, are significantly affected by temperature, besides showing high efficiency near $35^{\circ} \mathrm{C}$, which is the central temperature of the present study. Still, as stated by ZENG et al. (2010), for discontinuous anaerobic processes, the rate of STV $\mathrm{S}_{\mathrm{i}}$ is a key factor directly affecting the treatment efficiency, representing the biologically active biomass and being responsible for COD and $\mathrm{TVS}_{\mathrm{r}}$ removals.

Both temperature (linear term) and $\mathrm{TVS}_{\mathrm{i}}$ (linear and quadratic terms) significantly influenced the removal of $\mathrm{TVS}_{\mathrm{r}}$ since its $\mathrm{p}$-value was lower than the significance level of $10 \%$. The quadratic term of the temperature and of the interaction between temperature and $\mathrm{TVS}_{\mathrm{i}}$ had no statistical significance since their $\mathrm{p}$-values were greater than the adopted significance level. However, in order to increase the proportion of total response variability, explained by the regression model, no significant terms were kept in the representative mathematical model. 
TABLE 6. Analysis of variance for COD and TVS $\mathrm{r}_{\mathrm{r}}$ removals.

\begin{tabular}{|c|c|c|c|c|c|}
\hline & Factor & Sum of Squares & Degrees of freedom & Average Square & p_value \\
\hline \multirow{7}{*}{ COD Removal } & Temperature (LT) & 677.18 & 1 & 677.18 & $0.0637 *$ \\
\hline & Temperature (QT) & 1260.50 & 1 & 1260.50 & $0.0212 *$ \\
\hline & $\mathrm{TVS}_{\mathrm{i}}(\mathrm{LT})$ & 1074.66 & 1 & 1074.66 & $0.0289 *$ \\
\hline & $\mathrm{TVS}_{\mathrm{i}}(\mathrm{QT})$ & 6741.78 & 1 & 6741.78 & $0.0003 *$ \\
\hline & TxTVS $_{\mathrm{i}}$ & 2204.30 & 1 & 2204.30 & $0.0064 *$ \\
\hline & Residue & 789.08 & 6 & 131.51 & \\
\hline & Total & 12747.50 & 11 & & \\
\hline \multirow{7}{*}{ TVS $_{\mathrm{r}}$ Removal } & Temperature (LT) & 1357.29 & 1 & 1357.29 & $0.0164 *$ \\
\hline & Temperature (QT) & 71.68 & 1 & 71.68 & 0.4766 \\
\hline & $\mathrm{TVS}_{\mathrm{i}}(\mathrm{LT})$ & 604.92 & 1 & 604.92 & $0.0696^{*}$ \\
\hline & $\mathrm{TVS}_{\mathrm{i}}(\mathrm{QT})$ & 966.27 & 1 & 966.27 & $0.0317^{*}$ \\
\hline & TxTVS $_{\mathrm{i}}$ & 5.81 & 1 & 5.81 & 0.8361 \\
\hline & Residue & 746.58 & 6 & 124.43 & \\
\hline & Total & 3752.55 & 11 & & \\
\hline
\end{tabular}

Where *Statistically significant with a $90 \%$ confidence interval, LT refers to the linear term, while QT refers quadratic term of the equations 3 and 4 .

Table 7 shows the effects of the studied factors on response variables. A factor effect can be understood as response variance when all levels of this factor are gone through, regardless of other factors (RODRIGUES \& IEMMA, 2009). For COD removal, all factors and interaction between them were statistically significant. Temperature (linear term), $\mathrm{TVS}_{\mathrm{i}}$ (linear term), and interaction between them had positive effects, i.e. the transition from low level to the high level of the factors, increased the removal of carbonaceous organic matter in the reactor. According to KARAGIANNIDIS \& PERKOULIDIS (2009), increasing temperatures have a positive effect on the metabolic rate of microorganisms, speeding up the process. The findings also indicate that higher values of $S T V_{i}$ increase the removal of $S_{T V}$ (ZENG et al., 2010). Temperature and $S_{T V}$ (quadratic terms), as well as their interaction, had a negative effect on the removal of $\mathrm{TVS}_{\mathrm{r}}$, but being significant only $\mathrm{STV}_{\mathrm{i}}$ once p-value is lower than the significance level of $10 \%$.

TABLE 7. Analysis of effects of COD and TVS removals.

\begin{tabular}{|c|c|c|c|}
\hline & Factor & Effect & p-value \\
\hline \multirow{6}{*}{ COD Removal } & Average & 92.01 & $3.72 \mathrm{E}-06^{*}$ \\
\hline & Temperature (LT) & 18.43 & $0.0637 *$ \\
\hline & Temperature (QT) & -40.51 & $0.0043^{*}$ \\
\hline & $\operatorname{TVS}_{\mathrm{i}}(\mathrm{LT})$ & 23.21 & $0.0289 *$ \\
\hline & $\mathrm{TVS}_{\mathrm{i}}(\mathrm{QT})$ & -65.33 & $0.0003 *$ \\
\hline & TxTVS $_{\mathrm{i}}$ & 46.95 & $0.0064 *$ \\
\hline \multirow{6}{*}{$\mathrm{TSV}_{\mathrm{r}}$ Removal } & Average & 59.99 & $0.0000^{*}$ \\
\hline & Temperature (LT) & 26.09 & $0.0163 *$ \\
\hline & Temperature (QT) & -11.45 & 0.2434 \\
\hline & $\mathrm{TVS}_{\mathrm{i}}(\mathrm{LT})$ & 17.42 & $0.0696 *$ \\
\hline & $\mathrm{TVS}_{\mathrm{i}}(\mathrm{QT})$ & -24.68 & $0.0317^{*}$ \\
\hline & TxTVS $_{\mathrm{i}}$ & -2.41 & 0.8361 \\
\hline
\end{tabular}

* Statistically significant with a $90 \%$ confidence interval

Equations 8 and 9 show the process mathematical models of COD and TVS $\mathrm{r}_{\mathrm{r}}$ removals, respectively. The coefficients were estimated by multiple linear regression analysis using the least square method (Table 4) through Statistica software (version 7.0). This method is a mathematical optimization technique used to search for the best fit of the dataset by minimizing the sum of the squares of the differences between estimated and observed values. 


$$
\begin{aligned}
& \text { Removal COD }(\%)=92.01+9.21 \mathrm{x}_{1}-20.26 \mathrm{x}_{1}{ }^{2}+11.61 \mathrm{x}_{2}-32.66 \mathrm{x}_{2}{ }^{2}+23.48 \mathrm{x}_{1} \mathrm{x}_{2} \\
& \text { Removal TVS }(\%)=59.99+13.05 \mathrm{x}_{1}-5.73 \mathrm{x}_{1}{ }^{2}+8.71 \mathrm{x}_{2}-12.34 \mathrm{x}_{2}{ }^{2}-1.21 \mathrm{x}_{1} \mathrm{x}_{2}
\end{aligned}
$$
where,

$\mathrm{x}_{1}=$ encoded value of temperature,

$\mathrm{x}_{2}=$ encoded value of the rate of total volatile solids in inoculum.

Equation 10 shows how the coding process was carried out for temperature and $\mathrm{TVS}_{\mathrm{i}}$ in the mathematical models.

$$
\mathrm{x}_{\mathrm{i}}=\frac{z_{i}-z_{m}}{\frac{\Delta z}{2}}
$$

where,

$\mathrm{x}_{\mathrm{i}}=$ Encoded value of independent variable;

$\mathrm{Z}_{\mathrm{i}}=$ Real value of independent variable;

$\mathrm{Z}_{\mathrm{m}}=$ Mean value between the +1 and -1 levels,

$\Delta_{\mathrm{z}}$ Difference between the +1 and -1 levels.

Equations 11 and 12 express temperature and $\mathrm{TVS}_{\mathrm{i}}$ encoding for subsequent use in mathematical models, respectively.

$$
\begin{aligned}
& \mathrm{T}=\frac{\mathrm{T}_{e}-35}{7} \\
& \mathrm{TVS}_{\mathrm{i}}=\frac{\mathrm{TSV}_{\mathrm{i}(\mathrm{e})}-10}{2}
\end{aligned}
$$

where,

$\mathrm{T}=$ encoded value of temperature;

$\mathrm{T}_{\mathrm{e}}=$ temperature employed in anaerobic reactor $\left({ }^{\circ} \mathrm{C}\right)$;

$\mathrm{TVS}_{\mathrm{i}}=$ encoded value of the rate of total volatile solids in inoculum.

$\mathrm{TVS}_{\mathrm{i}(\mathrm{e})}=$ percentage of total volatile solids from the inoculum used in reactor $(\%)$.

\section{Statistical validity of the proposed mathematical models}

Table 8 displays the analysis of variance (ANOVA) for validation of the mathematical models. The quadratic models were statistically significant as p-values $(0.001$ and 0.041 , respectively) were below the significance level of $10 \%$.

The total variability of responses explained by the models were 94 and $80 \%$ for COD and $\mathrm{TVS}_{\mathrm{r}}$, respectively. In this context, we may infer that such mathematical models provided a good fit to the data. 
TABLE 8. Statistical validity of the mathematical model for COD and TVS $\mathrm{r}_{\mathrm{r}}$ removals.

\begin{tabular}{lcccccc}
\hline & Change & $\begin{array}{c}\text { Sum of } \\
\text { Squares }\end{array}$ & $\begin{array}{c}\text { Degrees of } \\
\text { freedom }\end{array}$ & Average Square & p-value & $\mathrm{R}^{2}$ \\
\hline COD Removal & Regression & 11958.42 & 5 & 2391.68 & $0.001^{*}$ & 0.94 \\
& Residues & 789.08 & 6 & 131.51 & & \\
\hline $\mathrm{TVS}_{\mathrm{r}}$ Removal & Total & 12747.50 & 11 & & & \\
\hline & Regression & 3005.97 & 5 & 601.19 & $0.041^{*}$ & 0.80 \\
& Residues & 746.58 & 6 & 124.43 & & \\
\hline
\end{tabular}

* Statistically significant at a $90 \%$ confidence interval.

Through the response surface approach (Figure 2), we could obtain the values of temperature and $\mathrm{TVS}_{\mathrm{i}}$ that promote higher removals of COD (Figure 2a) and $\mathrm{TVS}_{\mathrm{r}}$ (Figure $2 \mathrm{~b}$ ). For a higher COD removal, the optimum temperature range was between 34 and $39{ }^{\circ} \mathrm{C}$; yet regarding $\mathrm{TVS}_{\mathrm{i}}$, the values ranged from 9.0 to $11.0 \%$. Lastly, the optimum ranges of temperature and $\mathrm{TVS}_{\mathrm{i}}$ for maximization of $\mathrm{TVS}_{\mathrm{r}}$ removal were 40 to $44{ }^{\circ} \mathrm{C}$ and 10.0 to $12.0 \%$, respectively.

Since microorganisms are sensitive to thermal changes, the temperature has a direct effect on the efficiency of anaerobic processes, altering the speed of substrate utilization (KUMAR \& LIN, 2013; CAVINATO et al., 2017). Different studies evaluated the influence of temperature on the efficiency of anaerobic biodigestion (TIETZ et al., 2014; ZAMANZADEH et al., 2016; MONTAÑÉS et al., 2015). At very high temperatures, this efficiency is drastically reduced and, when a value of $65^{\circ} \mathrm{C}$ is achieved, the process virtually stops.

Both efficiency and stability of the anaerobic biodigestion can be improved by optimizing the inoculum/ substrate ratio (MOTTE et al., 2013; KAWAI et al., 2014). At high concentrations of $\mathrm{TVS}_{\mathrm{i}}$, the process efficiency is due to a limitation of the available substrate for the development of microbial biomass, which is relevant to the process since a less addition of inoculum into the anaerobic biodigester increase the amount of wastewater, without reducing the treatment efficiency.

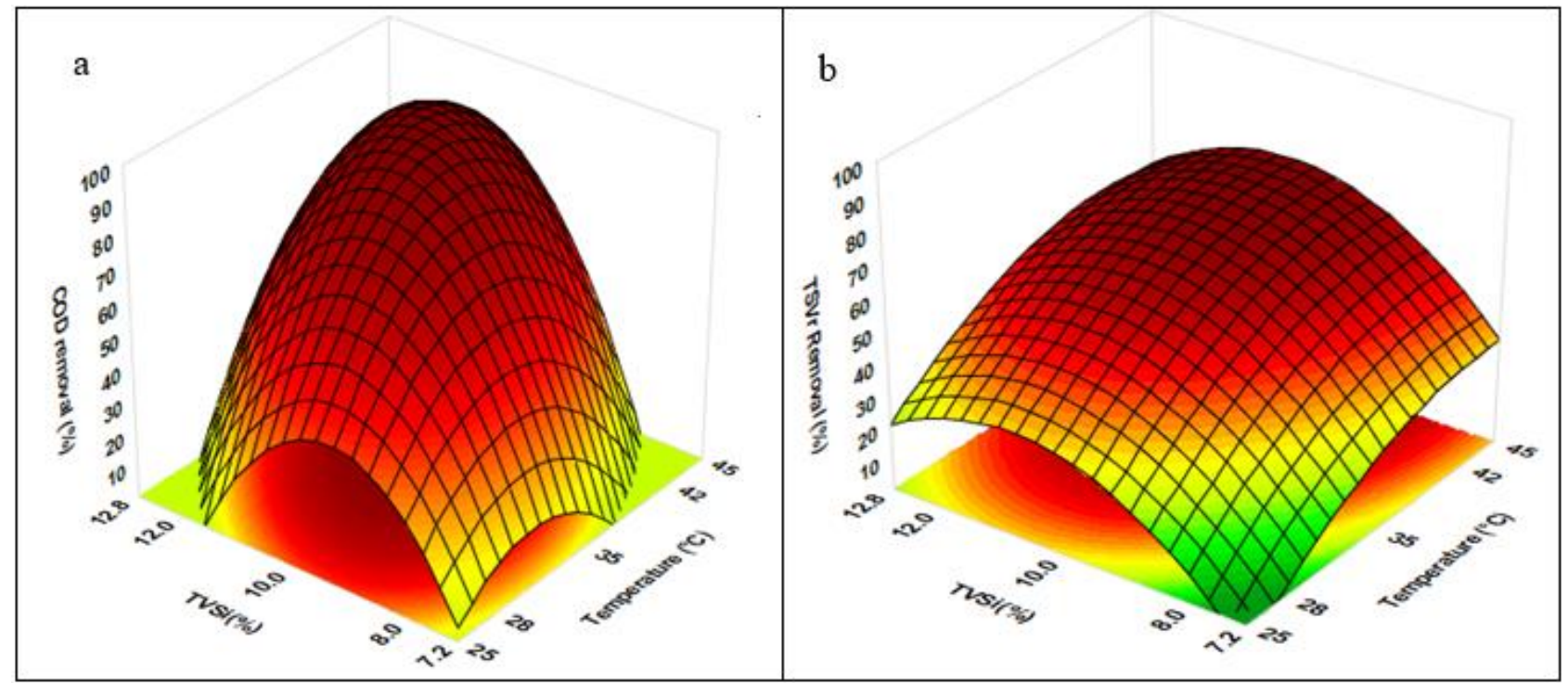

FIGURE 2. Response surface for COD (a) and $\mathrm{TVS}_{\mathrm{r}}(\mathrm{b})$ removals.

Using the desirability function approach proposed by DERRINGER \& SUICH (1980), we could assess the variables-responses simultaneously and find optimum operating values for the factors under study. Figure 3 shows the optimum values of temperature and $\mathrm{TVS}_{\mathrm{i}}$ that resulted in a major removal of COD and $\mathrm{TVS}_{\mathrm{r}}$, these values were $39.7^{\circ} \mathrm{C}(0.65707)$ and $10.75 \%$ of $\mathrm{TVS}_{\mathrm{i}}(\%)$ (0.37767). 
Temperature
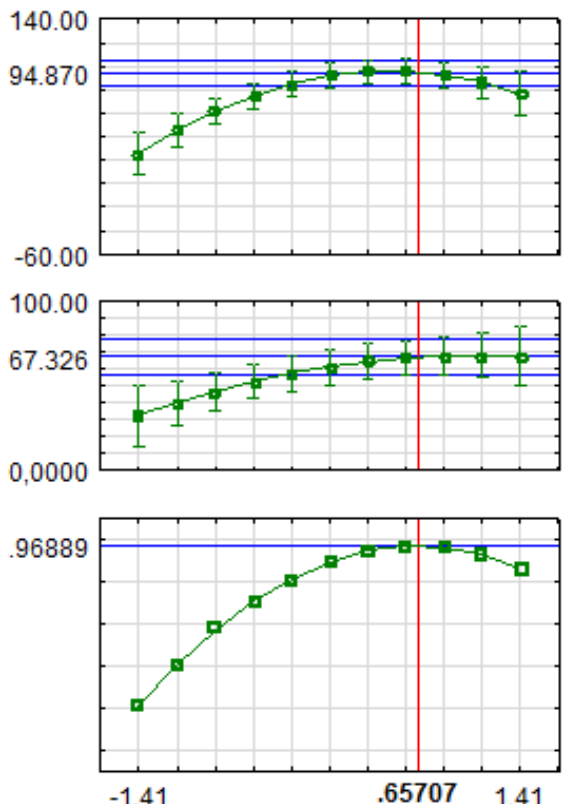

TVSi
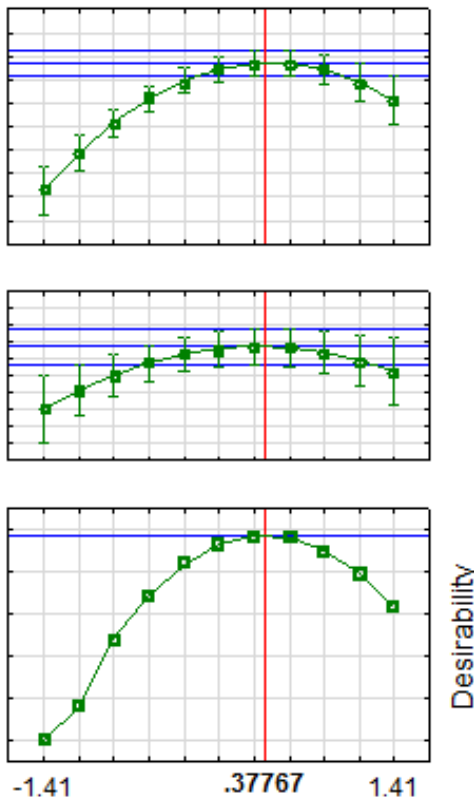

Desirability
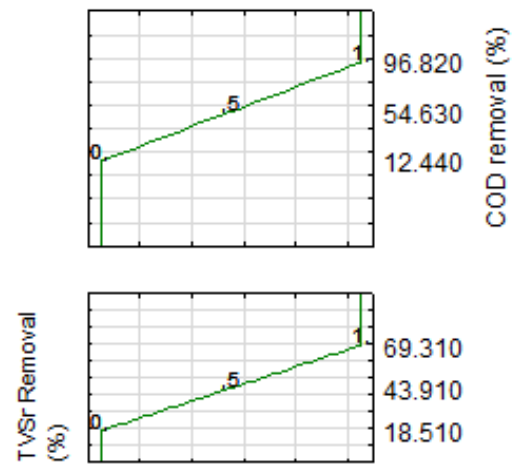

FIGURE 3. Application of the desirability function.

Table 9 exhibits the predicted and observed efficiencies for COD and $\mathrm{TVS}_{\mathrm{r}}$ removals regarding the optimal operation conditions of the anaerobic reactor. Furthermore, we must infer that the mathematical models satisfactorily described the COD and $\mathrm{TVS}_{\mathrm{r}}$ removal efficiency in the anaerobic reactor, with errors of 4.86 and $6.65 \%$, respectively.

TABLE 9. Experimental validation of the proposed mathematical models.

\begin{tabular}{lccc}
\hline Variable & Expected efficiency (\%) & Observed efficiency $(\%)$ & Error (\%) \\
\hline COD Removal & 94.85 & 90.45 & 4.86 \\
TVS $_{\mathrm{r}}$ Removal & 67.32 & 63.12 & 6.65 \\
\hline
\end{tabular}

\section{CONCLUSIONS}

Anaerobic biodigestion of wastewater from the processing of cassava proved to be an efficient technique for the removal of COD and $\mathrm{TVS}_{\mathrm{r}}$. Based on the desirability function approach, the optimal conditions of operation for the anaerobic reactor are $39.7{ }^{\circ} \mathrm{C}$ and $10.75 \%$ of $\mathrm{TVS}_{\mathrm{i}}$. However, satisfactory results for COD removal can be obtained within a temperature range between 34 and $39{ }^{\circ} \mathrm{C}$ and $\mathrm{TVS}_{\mathrm{i}}$ between 9.0 and $11.0 \%$. For a high removal of $\mathrm{TVS}_{\mathrm{r}}$, the anaerobic reactor should operate within a temperature range between 40 and $44{ }^{\circ} \mathrm{C}$ and $\mathrm{TVS}_{\mathrm{i}}$ between 10.0 and $12.0 \%$.

A high removal of carbonaceous organic material is important in anaerobic digestion in view of the later stages of the wastewater treatment, especially the aerobic one, once they are required to the removal of nutrients, mainly nitrogen.

Biogas production was discrepant in the system, what can be justified by an intrinsic variability of the biological process during wastewater treatment, besides influential factors disregarded in the present study. However, biogas composition was similar for all experimental conditions, with a high percentage of methane, which determines produced gas quality and applicability due to its heat capacity.

\section{ACKNOWLEDGMENTS}

We would like to thank the Federal University of Technology - Paraná, for making the laboratories available for the analysis and to the Araucaria Foundation and Itaipu Technological Park Foundation for the granted scholarship. 


\section{REFERENCES}

ADU-GYAMFI, N.; RAVELLA, S. R.; HOBBS, P. J. Optimization anaerobic digestion by selection of the immobilizing surface for enhanced methane production. Bioresource Technology, Oxford, v.120, n.1, p.248-255, 2012. DOI: 10.1016/j.biortech.2012.06.042

AHLBERG-ALIASSON, K.; NADEAU, E.; LEVÉN, L.; SCHNÜRER, A. Production efficiency of Swedish farm-scale biogas plants. Biomass and Bioenergy, Amsterdam, v.97, n.1, p.27-37, 2017. DOI: 10.1016/j.biombioe.2016.12.002

APHA. Standard methods for the examination of water and wastewater. $22^{\text {th }}$ ed. Washinton, DC: Ed. American Public Health Association, American Water Works Association, Water Environment Federation, 2012.

AWE, O. W.; ZHAO, Y.; NZIHOU, A.; MINH, D. P.; LYCZKO, N. A Review of Biogas utilization, purification and upgrading technologies. Waste and Biomass Valorization, Dordrecht, v.1, p.1-17, 2017. DOI: 10.1007/s12649-016-9826-4

CAVINATO, C.; ROS, C.; PAVAN, P.; BOLZONELLA, D. Influence of temperature and hydraulic retention on the production of volatile fatty acids during anaerobic fermentation of cow manure and maize silage. Bioresource Technology, Oxford, v.223, p.59-64, 2017. DOI: 10.1016/j.biortech.2016.10.041

CEREDA, M. P.; DAIUTO, E. R.; VILPOUX, O. Metodologia de determinação de amido por digestão ácida em microondas. Revista da Associação Brasileira dos Produtores de Amido de Mandioca, Paranavaí, v.2, p.29, 2004.

CHAN, Y.; CHONG, M.; LAW, C. Optimization of thermophilic anaerobic-aerobic treatment system for Palm Oil Mill Effluent (POME). Frontiers of Environmental Science \& Engineering, Beijing, v.9, n.2, p.334-351, 2015. DOI: 10.1007/s11783-014-0626-4

DAHUNSI, S. O.; ORANUSI, S.; OWOLABI, J. B.; EFEOVBOKHAN, V. E. Comparative biogas generation from fruit peels of fluted pumpkin (Telfairia occidentalis) and its optimization.

Bioresource Technology, Oxford, v.221, n.1, p. 517-525, 2016. DOI:

10.1016/j.biortech.2016.09.065

DERRINGER, G. C.; SUICH, R. Simultaneous optimization of several responses variables. Journal of Quality Technology, Milwaukee, v.12, n.4, p.214-219, 1980.

DOBRE, P.; NICOLAE, F.; MATEI, F. Main factors affecting biogas production - an overview. Romanian Biotechnological Letters, Bucharest, v.19, n.3, p.9283-9296, 2014.

FERRAZ, F. M.; BRUNI, A. T.; DEL BIANCHI, V. L. Performance of an Anaerobic Baffled Reactor (ABR) in treatment of cassava wastewater. Brazilian Journal of Microbiology, São Paulo, v.40, n.1, p.48-53, 2009. DOI: 10.1590/S1517-83822009000100007

INTANOO, P.; RANGSANVIGIT, P.; MALAKUL, P.; CHAVADEJ, S. Optimization of separate hydrogen and methane production from cassava wastewater using two-stage upflow anaerobic sludge blanket reactor (UASB) system under thermophilic operation. Bioresource Technology, Oxford, v.173, p.256-265, 2014. DOI: 10.1016/j.biortech.2014.09.039

IOVANE, P.; NANNA, F.; DING, Y.; BIKSON, B.; MOLINO, A. Experimental test with polymeric membrane for the biogas purification from $\mathrm{CO}_{2}$ and $\mathrm{H}_{2} \mathrm{~S}$. Fuel, London, v.135, n.1, p.352-358, 2014. DOI: 10.1016/j.fuel.2014.06.060

JAIN, S.; JAIN, S.; WOLF, I. T.; LEE, J.; TONG, Y. W. A comprehensive review on operating parameters and different pretreatment methodologies for anaerobic digestion of municipal solid waste. Renewable and Sustainable Energy Reviews, Oxford, v.52, p.142-154, 2015. DOI: 10.1016/j.rser.2015.07.091 
JIA, J.; TANG, Y.; LIU, B.; WU, D.; REN, N.; XING, D. Electricity generation from food wastes and microbial community structure in microbial fuel cells. Bioresource Technology, Oxford, v.144, p.94-99, 2013. DOI: 10.1016/j.biortech.2013.06.072

JUMBRI, K.; ROZY, M. F. A.; ASHARI, S. E.; MOHAMED, R.; BASRI, M.; MASOUMI, H. R. F. Optimisation and Characterisation of Lipase-Catalysed Synthesis of a Kojic Monooleate Ester in a Solvent-Free System by Response Surface Methodology. Plos One, Lawrence, v.10, n.12, p. 113, 2015. DOI: 10.1371/journal.pone.0144664

KARAGIANNIDIS, A.; PERKOULIDIS. A multi-criteria ranking of different technologies for the anaerobic digestion for energy recovery of the organic fraction of municipal solid wastes.

Bioresource Technology, Oxford, v.100, n.8, p.2355-2360, 2009. DOI:

10.1016/j.biortech.2008.11.033

KAWAI, M.; NAGAO, N.; TAJIMA, N.; NIWA, C.; MATSUYAMA, T.; TODA, T. The effect of the labile organic fraction in food waste and the substrate/inoculum ratio on anaerobic digestion for a reliable methane yield. Bioresource Technology, Oxford, v.157, n.1, p.174-180, 2014. DOI: 10.1016/j.biortech.2014.01.018

KPATA-KONAN, N. E.; TEÓPHILE, G.; FÉLIX, K. K.; YVES, B. K.; MARTIN, K. K.; FRANCIS, K. Y.; KABLAN, T. Improving anaerobic biodigestion of manioc wastewater with human urine as co-substrate. International Journal of Innovation and Applied Studies, Kabat, v.2, n.3, p.335-343, 2013.

KUCZMAN, O.; GOMES, S. D.; TAVARES, M. H. F.; TORRES, D. G. B.; ALCÂNTARA, M. S. Produção especifica de biogás a partir de manipueira em reator de fase única. Engenharia Agrícola, Jaboticabal, v.31, n.1, p.143-149, 2011. DOI: 10.1590/S0100-69162011000100014

KUCZMAN, O.; TAVARES, M. H. F.; GOMES, S. D.; GUEDES, L. P. C.; GRISOTTI, G. Cassava starch extraction effluent treatment in a one phase tubular horizontal pilot reactor with support medium. Engenharia Agrícola, Jaboticabal, v.34, n.6, p.1270-1282, 2014. DOI: 10.1590/S0100-69162014000600021

KULlaVANIJAYA, P.; THONGDUANG, P. Enhanced Biogas Production in Anaerobic Digestion of Cassava Wastewater Though Supplementation of Biodiesel Waste as Co-Substrate.

International Journal of Renewable Energy Research, Kabat, v.2, n.3, p.510-515, 2012.

KUMAR, G.; LIN, C. Bioconversion of de-oiled Jatropha Waste (DJW) to hydrogen and methane gas by anaerobic fermentation: Influence of substrate concentration, temperature and $\mathrm{pH}$.

International Journal of Hydrogen Energy, Oxford, v.38, n.1, p.63-72, 2013. DOI:

10.1016/j.ijhydene.2012.10.053

KUNZLER, K. R.; GOMES, S. D.; PIANA, P. A.; TORRES, D. G. B.; VILAS BOAS, M. A.; TAVARES, M. H. F.Anaerobic reactors with biofilter and different diameter-length ratios in cassava starch industry wastewater treatment. Engenharia Agrícola, Jaboticabal, v.33, n.4, p.612624, 2013. DOI: 10.1590/S0100-69162013000400003

KWIETNIEWSKA, E.; TYS, J. Process characteristics, inhibition factors and methane yields of anaerobic digestion process, with particular focus on microalgal biomass fermentation. Renewable and sustainable energy reviews, Oxford, v.34, n.1, p. 491-500, 2014. DOI:

10.1016/j.rser.2014.03.041

LOURES, C. C. A.; IZÁRIO FILHO, H. J.; OLIVEIRA, I. S.; SAMANAMUD, G. R. L.; SOUZA, A. L.; SILVA, M. B. The Application of Response Surface Methodology in the Study of Photodegraded Industrial Dairy Effluents by the Photo-Fenton Process: Optimization and Economic Viability. International Scholarly Research Notices, New York, v.2014, p.1-9, 2014. DOI: $10.1155 / 2014 / 967534$ 
MÉNDEZ-ACOSTA, H. O.; HERNADEZ-MARTINEZ, E.; JÁUREGUI-JÁUREGUI, J. A.; ALVAREZ-RAMIREZ, J. PUEBLA, H. Monitoring anaerobic sequential batch reactors via fractal analysis of $\mathrm{pH}$ time series. Biotechnology and Bioengineering, New York, v.110, n.8, p.21312139, 2013. DOI: 10.1002/bit.24838

MIRANDA, A. P.; LUCAS JUNIOR, J.; THOMAZ, M. C.; PEREIRA, G. T.; FUKAYAMA, E. H. Anaerobic biodigestion of pigs feces in the initial, growing and finishing stages fed with diets formulated with corn or sorghum. Engenharia Agrícola, Jaboticabal, v.32, n.1, p.47-56, 2012. DOI: $10.1590 / \mathrm{S} 0100-69162012000100006$

MONDARDO, A. A.; SOUZA, S. N. M.; ROVARIS, S. A.; ALMEIDA, C.; GOMES, G. J.; VENZON, S. S.; SANTOS, R. F.; SIQUEIRA, J. A. C. Quali-Quantitative study of biogas production from bio-digestion of cutting poultry. African Journal of Agricultural Research, Nigeria, v.11, n.37, p.3506-3513, 2016. DOI:10.5897/AJAR2016.11328

MONTAÑÉS, R.; SOLERA, R.; PÉREZ, M. Anaerobic co-digestion of sewage sludge and sugar beet pulp lixiviation in batch reactors: Effect of temperature. Bioresource Technology, Oxford, v.180, p.177-184, 2015. DOI:10.1016/j.biortech.2014.12.056

MOTTE, J. C.; ESCUDIÉ, R.; BERNET, N.; DELGENES, J. P.; STEYER, J. P.; DUMAS, C. Dynamic effect of total solid content, low substrate/inoculum ratio and particle size on solid-state anaerobic digestion. Bioresource Technology, Oxford, v.144, n.1, p.141-148, 2013. DOI: 10.1016/j.biortech.2013.06.057

NOOR, M. M.; WANDEL, A. P.; YUSAF, T. Effect of air-fuel on temperature distribution and pollutants for biogas mild combustion. International Journal of Automotive and Mechanical Engineering, v.10, p.1980-1992, 2014. DOI: 10.15282/ijame.10.2014.15.0166

PEREIRA, E. L.; CAMPOS, C. M. M.; MOTERANI, F. Efeitos do pH, acidez e alcalinidade de um reator anaeróbio de manta de lodo (UASB) tratando efluentes de suinocultura. Revista Ambiente \& Água, Santa Maria, v.4, n.3, p.157-168, 2009. DOI: 10.4136/ambi-agua.109

PEREIRA, E. L.; CAMPOS, C. M. M.; MOTTERAN, F. Physicochemical study of pH, alkalinity and total acidity in a system composed of Anaerobic Baffled Reactor (ABR) in series with Upflow Anaerobic Sludge Blanket Reactor (UASB) in the treatment of pig farming wastewater. Acta Scientiarum, Maringá, v.35, n.3, p.477-483, 2013. DOI: 10.4025/actascitechnol.v35i3.14069

RIPLEY, L. E.; BOYLE, W. C.; CONVERSE, J. C. Improved alkalimetric monitoring for anaerobic digestion of high-strength wastes. Journal of water pollution control federation, Washington, v.58, n.5, p.406-411, 1986.

RODRIGUES, M. R.; IEMMA, A. F. Planejamento de experimentos e otimização de processos. 2. ed. São Paulo: Cárita, 2009.

SCHIRMER, W. N.; JUCÁ, J. F. T.; SCHULER, A. R. P.; HOLANDA, S.; JESUS, L. L. Methane production in anaerobic digestion of organic waste from Recife (Brazil) landfill: evaluation in refuse of different ages. Brazilian Journal of Chemical Engineering, São Paulo, v.31, n.2, p. 373384, 2014. DOI: 10.1590/0104-6632.20140312s00002468

STRÖMBERG, S.; NISTOR, M.; LIU, J. Towards eliminating systematic errors caused by the experimental conditions in Biochemical Methane Potential (BMP) tests. Waste Management, v.34, p.1939-1948, 2014. DOI: 10.1016/j.wasman.2014.07.018

SUMAN, P. A.; URBANO, L. H.; LEONEL, M.; MISCHAN, M. M. Efeitos de parâmetros de fermentação na produção de etanol a partir de resíduo líquido da industrialização da mandioca (manipueira). Acta Scientiarum Technology, Maringá, v.33, n.4, p.379-384, 2011. DOI: 10.4025/actascitechnol.v33i4.9279

TIETZ, C. M.; ZENATTI, D. C.; FEIDEN, A.; LUPATINI, K. N.; CORRÊIA, A. F. Influência da temperatura na produção de biogás a partir de dejetos da bovinocultura de leite. Revista Brasileira de Energias Renováveis, Curitiba, v.3, p.80-96, 2014. 
WANG, W; XIE, L; LUO, G; ZHOU, Q; LU, Q. Optimization of biohydrogen and methane recovery within a cassava ethanol wastewater/waste integrated management system. Bioresource Technology, Oxford, v.120, n.1, p.165-172, 2012. DOI: 10.1016/j.biortech.2012.06.048

WARD, A. J.; HOBBS, P. J.; HOLLIMAN, P. J.; JONES. D. L. Optimisation of the anaerobic digestion of agricultural resources. Bioresource Technology, Oxford, v.99, n.17, p.7928-7940, 2008. DOI: 10.1016/j.biortech.2008.02.044

ZAMANZADEH, M.; HAGEN, L. H.; SVENSSON, K.; LINJORDET, R.; HORN, S. J. Anaerobic digestion of food waste - Effect of recirculation and temperature on performance and microbiology. Water Research, Oxford, v.96, n.1, p.246-254, 2016. DOI: 10.1016/j.watres.2016.03.058

ZENG, S.; YUAN, X.; SHI, X.; QIU, Y. Effect of inoculum/substrate ratio on methane yield and orthophosphate release from anaerobic digestion of Microcystis spp. Journal of Hazardous Materials, New York, v.178, n.1-3, p. 89-93, 2010. DOI: 1016/j.jhazmat.2010.01.047

ZHANG, Q; HE, J; TIAN, M; MAO, Z; TANG, L; ZHANG, J; ZHANG, H. Enhancement of methane production from cassava residues by biological pretreatment using a constructed microbial consortium. Bioresource Technology, Oxford, v.102, n.19, p.8899-8906, 2011. DOI:

10.1016/j.biortech.2011.06.061 